\title{
THE PROBLEM OF CORRELATION OF PSYCHOLOGICAL SCIENTIFIC KNOWLEDGE AND MODERN PRACTICAL METHODS OF DIAGNOSIS AND INTERVENTION
}

\author{
Babajanyan I. H. (Aurora Behavioral Charter Oak, California, USA) \\ i.babajanyan95@gmail.com

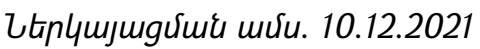 \\ 9pmpunuर्याध mर्जu. 27.12.2021

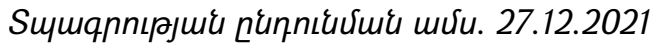

\begin{abstract}
The article is aimed at substantiate the need of taking into account the epistemological principles in the process of applying methods of psychological assessment, counseling and intervention, which in turn can contribute to the purposeful preservation of the physical and mental health of a person. Modern psychological assessment is an important scientific and applied component of psychological cognition. A reliable psychological assessment of individual personality traits and its mental state is of categorical importance, since it is aimed at identifying a specific and situational phenomenon for the further use of various practices. In this regard, a practical psychologist must possess the professional skills of psychological diagnostics, which implies the ability to establish connections between the external signs of a phenomenon and the internal psychological characteristics of a person. In this case, a special role is assigned to the epistemological foundations of psychological science and practice, which directly affect the formation of the methodology of counseling, therapy and training.
\end{abstract}

Keywords: methodology, epistemological principles, personality, psychological assessment, diagnosis, intervention, therapy.

DOI: https://doi.org/10.46991/SBMP/2022.5.1.025

Psychological research involves the use of methods of reliable psychological assessment, that is, questionnaires and tests for diagnosing individual personality traits and his/her mental state. This process is of categorical importance both for academic science and for practical psychology, since it is aimed at identifying a specific and situational phenomenon for the further application of various interventions. In this regard, the education of psychologists should be aimed at mastering the professional skills of psychological assessment, which implies the ability to establish connections between the external signs of a phenomenon and the internal psychological characteristics of a person. 
A wide range of modern social, technological, informational and environmental transformations poses new challenges for theoretical and applied psychology. Some of those challenges are: the reformation of scientific discourses, methodological approaches, and ways of practical work, which in general influences the aspects of scientific thinking. In this context, the statement of Morin E. is worth mentioning; "We ask thought to dispel fogs and obscurities, to bring order and clarity to reality, to reveal the laws that govern it" [6].

Psychological science, studying the structure of the psyche, behavior and psychic state of a person, emphasizes the importance of the psychological aspect of the preservation, restoration and prophylaxis of human health. In this regard, the physiological, behavioral and social factors are distinguished that make it possible to understand the characteristics of a person's development during life, in the process of playing, learning and working, the structure of his personality, motivation, experiences, emotions and stressful conditions, social behavior and attitudes.

One of the critical articles focuses on how psychologists "psychologize" the scientific psychology, pointing out that such "psychologization" requires additional conceptual work, especially when it uses the works of philosophical science [4].

In 1996 the subject of a wide discourse of Russian psychology was the issue of the gap between scientific and applied psychology, since the latter gained freedom during this period, it was carried away by various theories and began to develop rapidly. According to Vasilyuk F., psychological practice and psychological science moved into parallel worlds and lost interest in each other. Turning to the cultural-historical concept, the author reveals the meaning of the fact that Vygotsky L.S. understood the very consciousness as "cultural" and "practical" in its genesis and structure and functioning [13]. It is known that Vygotsky's scientific views have deep philosophical roots. Further, it is noted that early psychoanalysis was carried out already as an independent psychological practice, which, whether or not, is based on the philosophical teachings of Plato, Schopenhauer, Nietzsche and others. Accordingly, if the practicing psychologist keeps to scientific psychological knowledge, it will enable to determine the correlation between academic and practical psychology, as well as outline the difference with pop psychology.

The epistemological basis of psychological science directly influence the formation of the methodology of applied psychology, thereby giving practical knowledge of how to work with individual or group clients, how to conduct counseling or therapeutic procedures. Karitskiy I.N. precisely noted that the methodological foundations of psychological practice set its structure as direct activity, guide and organize the process of psychologist's activity [14]. 
In this regard, the education of psychologists in order to fully master professional knowledge and skills should symmetrically combine theoretical and practical studies. Research projects of students, as a rule, are summarized by statements of facts, analysis of dates of data that are intended to test hypotheses. But, we know that psychological diagnostics are also designed to search for means of targeted influence, to reveal the mechanisms of mental regulation, correction and control of behavior, the state of a person, his communicative interaction, etc. At the same time, it is necessary to take into account the fact that when making a diagnosis; specific operations are carried out with a concrete purpose and special epistemological content and a logical conclusion about a person's condition, based on a methodological study of his characteristic features [15]. There are known statements about the importance of taking into account theoretical background in the process of psychological measurements, namely, in the projective procedure of psychological diagnostics [2].

Sarason I. mentions that among the main problems in the study of the personality assessment is the question of; which of the many personality constructs that have been quantified are basic or fundamental and which, as one can expect, will require wasted efforts in their assessment, since they are illdefined combinations of more elementary constructs; what measurement methods are the most effective and convenient for assessment; and whether it is better to interview people to assess personality or ask them to say, for example, what an inkblot or cloud in the sky reminds them of [10].

Psychology as a discipline of behavioral health is a key to biopsychosocial practice and plays an important role in understanding the concept of health and disease. In general, psychologists assess, diagnose and treat psychological problems and behavioral dysfunctions arising from or connected with physical and mental health. In addition, they play an important role in promoting healthy behavior, preventing diseases and improving the quality of life of patients. [9]

Many authors have noticed the modern tendencies that the main approaches and techniques of individual and group psychotherapy contribute to the development of new training programs to teach patients the methods of personal growth, self-control and self-regulation. In this regard, tendencies of integration, merging or complementarity of various psychotherapeutic schools are outlined.

Bishop M. and Trout J. D. considering the main modern theories of Standard Analytical Epistemology (SAE), including various versions and conceptual approaches (Chisholm, 1981; Pollock, 1974; Bonjour, 1985; Lehrer, 1974; Dretske, 1981; Goldman, 1986; DeRose, 1995 and Lewis, 1996) aims to show that the standard argument against naturalized epistemology has an opposite flip side. Of the five theses proposed by the author, we drew attention to the following: some of the advanced psychological sciences over the past half 
century are deeply normative and provide specific recommendations on how to improve reasoning on issues of great practical importance [3].

It is considered that one of the reasons why opinions differ about the influence of psychology on epistemology is the distinction in the conceptual approach to the goals of epistemology itself. To analyze this influence, Goldman A. I. identified three such concepts, namely, descriptive, analytical and normative epistemology. The author further notes that if the first of these concepts is accepted, there should be no doubt that psychology plays a vital role. On the contrary, if the third concept is accepted, it may seem highly questionable that psychology plays any role at all. The role that psychology can play in descriptive and analytical epistemology is examined, and then, more detailed attention to normative epistemology is given. As a result of this approach it is proved that psychology can make an important contribution even to normative epistemology, and also substantiate the close connection between psychological research and epistemology [5].

Based on the historical and theoretical deliberations, it is established that speculations should not be eradicated from psychology and that they are a necessary part of empirical conclusions, especially when they are concerned with data interpretation. The quality of these interpretive hypotheses, that is, the hermeneutics of empirical psychology about research data, is especially important when they relate to groups of people and the differences between them. Thomas Teo asserts that the identified reconstructions and arguments derived from detailed analysis provide an interpretation of speculation and interpretation problems in empirical psychology. Consequently, hermeneutics becomes critical if it has a position that does not take the self-understanding of mainstream psychology for granted, but tries to expose the epistemological and ethical flaws of the status quo. In this article, the author approves that one way or another "speculation is a ghost that has accompanied psychology throughout its history [11]." In the famous academic research blog "LSE Impact Blog" the important message is highlighted that today the representatives of the social science can help politicians and colleagues develop solutions that people can and, what is more important, are willing to implement. Of course, this relates to the most actual question today: "What is the role of the social sciences in the response to COVID-19?" [12]. It can be assumed about certain epistemological changes that are typical for modern social sciences and, in particular, practical psychology. This poses new challenges for scientific researches that provide a practical way out. Analysis of many scientific articles and books on the problem of how and how much psychologists have practically adhered to the existing theoretical basis and conceptual approaches indicated the hypothesizing and planning our empirical research. 
The hypothesis of this stage of the study, connected with the need to assess epistemological elements in psychological practice, envisaged finding answers to the following questions:

-What epistemological principles does the psychologist keep; follow in the process of psychological practice (in assessing the personality and his condition, in psychological counseling and therapy)?

- How and to what extent do modern lexical innovations and the information field affect the vocabulary content of psychological assessment texts (conversation, survey, tests) and interventions (training, counseling and therapy)?

- Are there differences in the perception of the lexicon of the psychologist and the patient?

- What theoretical approaches and academic achievements do psychologists use in promoting practical psychological services?

Presumably, the answers to these questions make it possible to emphasize the importance of preserving scientific psychological knowledge in the process of applying modern methods of diagnosis and intervention. Confirmation of the actuality of the selected problem can be facilitated by a detailed survey of psychologists-experts, as well as an analysis of the content of modern sources of presentation and promotion of psychological services.

\section{References}

1. Alvin I. Goldman. The Relation between Epistemology and Psychology. Synthese, Vol. 64, No. 1, Naturalistic Epistemology, Part I (Jul. 1985), pp. 29-68. https://www.jstor.org/stable/20116146. (17.10.2021).

2. Avanesyan H. The Theoretical Background of Application of Projective Methods in Experimental Studies. Yerevan University Bulletin. Philosophy, Psychology, 2017, No. 1, (22): pp. $42-51$. https://doi.org/10.46991/BYSU:E/2017.8.1.042. (10.11.2021)

3. Flis I. Psychologists psychologizing scientific psychology: An epistemological reading of the replication crisis. Theory \& Psychology. Volume: 29 issue: 2, pp.158-181. https://doi.org/10.1177/0959354319835322

4. Morin E. (2005) Introduction à la pensée complexe, Paris, Éditions du Seuil, Theory \& Psychology. Volume: 29 issue: 2, pp. 158-181. https://doi.org/10.1177/0959354319835322 (25.11.2021)

5. Michael B. and J. D. Trout. (2005) The Pathologies of Standard Analytic Epistemology. Noûs, Vol. 39, No. 4 (Dec. 2005), pp. 696-714. https://www.jstor.org/stable/3506117 (14.10.2021). 
6. Saeed H. Wahass (2005) The Role of Psychologists in Health Care Delivery//J Family Community Med. 2005 May-Aug; 12(2): pp. 63-70. https://www.ncbi.nlm.nih.gov/pmc/articles/PMC3410123/ (13.11.2021).

7. Sarason, Irwin G. "Personality assessment. Psychology". Encyclopedia Britannica, 1 Oct. 2019, https://www.britannica.com/science/personality -assessment. (Accessed 6 December 2021).

8. Thomas T. (2008) From Speculation to Epistemological Violence in Psychology: A Critical-Hermeneutic Reconstruction. First Published February 1, 2008; pp. 47-67. DOI: 10.1177/0959354307086922. (24.10.2021).

9. What is the role of the social sciences in the response to COVID-19? https://blogs.lse.ac.uk/impactofsocialsciences/ (02.12.2021).

10.Василюк Ф. Е. Методологический смысл психологического схизиса // Вопросы психологии. 1996. № 6. с. 25-40. http://psylib.org.ua/books/_vasif03.htm (05.11.2021).

11. Карицкий И.Н. Базовая структура психологической практики. Перспективы психологической науки и практики: сборник статей Международной научно-практической конференции. РГУ им. А. Н. Косыгина/ под ред. В.С. Белгородского и др.М.: ФГБОУ ВО «РГУ им. А.Н. Косыгина», 2017. с. 64, с.62-66 (15.11.2021).

12. Костромина С.Н. Психологический диагноз: классификация и типология//Вестник Санкт-Петербургского университета. Политология. Международные отношения. 2007. № 2-1. https://cyberleninka.ru/article/n/psihologicheskiy-diagnoz-klassifikatsiyai-tipologiya (13.11.2021). 